\title{
Prices in the Politburo, 1927: Market Equilibrium Versus the Use of Force*
}

\author{
Mark Harrison \\ Department of Economics \\ University of Warwick \\ Centre for Russian \& East European Studies \\ University of Birmingham \\ and \\ Hoover Institution on War, Revolution, and Peace \\ Stanford University
}

\begin{abstract}
In January 1927 the ruling core of the Bolshevik party met to discuss progress towards cutting the retail prices of industrial commodities. This policy was intended to reconcile the interests of urban and rural households with those of the state, and keep peasant farmers supplying food on a scale sufficient to meet the needs of state-led industrialization. The policy was difficult to implement because it ran counter to the requirements of market equilibrium, while the implied squeeze on trading costs and profits also generated widespread resistance. The Bolshevik leaders faced a choice between allowing the market to return to equilibrium and imposing the desired prices and quantities by force. The verbatim minutes of their discussion, available for the first time, show us how they perceived this choice before they made it.
\end{abstract}

JEL Codes: N14, P16.

* This is a draft chapter for The Lost Politburo Stenograms, edited by Paul R. Gregory, in preparation. It contributes to a programme of research on the political economy of the Soviet Union funded by the Hoover Institution, Stanford University. I thank the Hoover Institution and Archive for their hospitality in July 2006 when this paper was written, the University of Warwick North America Travel Fund for financial support, and R.W. Davies, Michael Ellman, Simon Ertz, and Paul Gregory for advice and comments.

" Address for correspondence: Department of Economics, University of Warwick, Coventry CV4 7AL, UK. Email: mark.harrison@warwick.ac.uk.

First draft: 27 July 2006. This version: 1 September 2006. 


\section{Prices in the Politburo, 1927: Market Equilibrium Versus the Use of Force}

The Politburo met on January 3, 1927, to discuss progress towards cutting the retail prices of industrial commodities. ${ }^{1}$ The meeting itself had no great influence on events. The policy of cutting retail prices had been previously adopted - at the party central committee plenum in April 1926 - and was already in effect. The policy was supported by a broad consensus of those present and taking part, although the Left opposition was no longer represented in the Politburo. ${ }^{2}$ The main purpose of the meeting was evidently to review progress, which had been difficult. The main outcome was to refer the discussion to a subcommittee that already existed, and to reinforce its membership (Annexe 1). The discussion is of interest today because it shows the Bolshevik leaders debating the role of market equilibrium versus the use of force in the allocation of resources.

The verbatim record teases us with fleeting glimpses of individual leaders at work. The discussion is led by Mikoian, and chaired actively by Rykov. ${ }^{3}$ These come across as worthy prefects, able to manage detail, and to make a point sharply, but with no great sense of occasion or mission. Stalin is already the teacher, disciplining the classroom from time to time by bringing the pupils back to fundamentals when they stray from the point: "It should be emphasized," he demanded, that the matters under discussion "present a most serious danger, that the struggle against this danger is one of the most important tasks of our party. All this should have been emphasized, but this, unfortunately, comrade Mikoian's report does not do" $(\S 113) .{ }^{4}$ Bukharin is the class wit; his classmates laugh at his jokes (§303), but he also makes a clever, substantive intervention ( $\$ 329)$ that wins Stalin’s approval. ${ }^{5}$ Kalinin is the boy

${ }^{1}$ RGASPI, 17/163/703. Files 701 and 702 contain the transcript in the original and showing the editorial and authors' corrections. References in the text (e.g. §113) are to the paragraphs of the transcript numbered in sequence.

${ }^{2}$ The background to the policy of price reductions in 1926 and 1927 is covered in more detail by Carr and Davies (1974, pp. 715-737).

${ }^{3}$ A.I. Mikoian (1895-1978): in 1927, member of the party central committee and candidate Politburo member; also minister of domestic and foreign trade of the USSR. A.I. Rykov (1881-1938): in 1927, Politburo member; also prime minister as chairman of Sovnarkom, the USSR Council of Ministers; also chairman of STO, the Council of Labor and Defense. These and other personal data given below, unless it is stated otherwise, are taken from Ivkin (1999) and Goriachev (2005).

${ }^{4}$ I.V. Stalin (1879-1953): in 1927, Politburo member and general secretary of the central committee of the Bolshevik Party.

${ }^{5}$ N.I. Bukharin (1888-1938): in 1927, Politburo member. 
who would like everyone to be nice. ${ }^{6}$ Kosior is the voice of the real world outside the classroom: there's trouble in the playground; something must be done. ${ }^{7}$ Others help to carry the drama along but do not stand out for their roles in the plot.

The wider context is this. After nearly three years of suspension during the Russian civil war the Bolsheviks returned the urban-rural market to legality in March 1921 - too late to avert a bitter famine in the winter of that year that may have cost six million lives (Davies and Wheatcroft 1994, p. 64).

Agriculture was in ruins; so was industry. After that, the economy recovered.

A core process driving the recovery was the restoration of urban-rural exchange. Peasants grew foodstuffs, tobacco, fibers, and by-products of animal husbandry such as wool and leather, which they sold on the market to urban consumers and producers for cash. They used this cash to buy industrial commodities: salt, refined sugar, matches, fabrics, metal goods and farm implements. Firms located in the towns and cities, often state-owned, supplied these goods for cash; in turn, they and their workers were able to purchase the unprocessed foods and materials they required of agriculture. This classical process of Smithian specialization and exchange returned the Soviet economy to something close to prewar levels of output and employment by the later 1920s (Gregory 1990, p. 247; Harrison 1994, pp. 41-42).

The recovery process was marked by two crises in the urban-rural market, the "scissors" crisis of 1922/23 and the grain procurement crisis that began at the end of 1927. How the scissors crisis got its name is shown in Figure 1: in the second half of 1922 there was a rapid divergence of relative prices of immense proportions that, when illustrated on a graph, looked like a pair of scissors with the blades opening. Ever after, commentators referred to the real price of industrial goods as the "scissors." When the price rose, the scissors opened; when it fell, they closed. Participants in the Politburo meeting also extended the metaphor to other contexts: the "wholesale-retail scissors," for example (Mikoian, §7), meant the gap between wholesale and retail prices of the same goods; another "urban-rural" scissors involved higher prices for the same goods in villages compared with urban retail outlets (Rykov, §217).

The course of the scissors crisis was as follows (the classic account is by Carr 1969). The civil war was over. Agricultural production was recovering from the famine of 1921, while industry struggled to reorganize and recover. Industrial prices rose and agricultural prices fell away. By October 1923, the real price of industrial goods, measured in food units, reached more than three times the prewar relativity. (This was true of both retail and wholesale prices, but the chart reminds us that the retail and wholesale scissors could and did move independently in some degree.) Faced with such disadvantageous terms, the peasants failed to return to the market with their food supplies for the hungry towns. The Soviet state took action to close the scissors and this

${ }^{6}$ M.I. Kalinin (1875-1946): in 1927, Politburo member; also head of state as president of VTsIK, the All-Union Central Executive Committee of the USSR.

${ }^{7}$ S.V. Kosior (1889-1939), in 1927, one of the secretaries of the party central committee; or I.V. Kosior, member of the board of VSNKh, the ministry for state industry (Carr and Davies 1974, p. 338)? 
brought the peasants back to the market. But the scissors were not shut completely. For this reason and others, analysed in detail by Harrison (1990), food marketing never recovered to the levels witnessed before the world war and revolution. During 1925 and 1926, moreover, the scissors tended to spring open again. As Figure 2 suggests, wholesale prices were not such a source of concern, at least by the standards of 1922/23, but the divergence of retail prices became quite marked again in the mid-1920s and this was both a worry and a puzzle.

When the Politburo met in January 1927 a second crisis, the food marketing crisis of 1928 and 1929, lay just around the corner. Unlike the first, it would prove terminal; it provoked suspension of the market followed by the eventual destruction of the entire system of peasant farming.

The food marketing crisis of 1928 and 1929 and the scissors crisis of 1922/23 bear superficial similarities. In each crisis peasants became unexpectedly reluctant to bring their products to the market; this threatened the supply of food and raw materials to industry, urban households, the armed forces, and exports that were urgently needed to earn scarce foreign currency. In each crisis the relative price of manufactures on the urban-rural market appeared to be excessively high. The first crisis was apparently resolved when the authorities intervened to forced down the price of industrial commodities; following this intervention, food marketings recovered and economic expansion was resumed. The authorities concluded that they had succeeded in mastering the laws of the market.

Yet when the same policies were applied in an apparently similar context a few years later the results were exactly opposite: industrial prices were pressed down, but this time food supplies deteriorated. In short, an intervention that stabilized the economic recovery in 1923 proved destabilizing when attempted a second time in 1927, with far-reaching consequences: eventually the lives of a hundred million people were turned upside down, and a significant proportion of them were tragically curtailed. When the Politburo met in January 1927, however, the consequences lay in the future.

I will focus on three aspects of the discussion that took place in this context: the motivations behind the policy of price reductions, its feasibility given the resistance encountered in attempting to implement it, and the range of methods that were contemplated to enforce the policy.

\section{Motivations}

In calling for retail price cuts in 1926/27 the Bolshevik leaders were intervening against the market. At a general level, the motivation for cutting industrial prices does not emerge strongly from the Politburo debate.

Mikoian's written report mentioned it only briefly before launching into the technicalities of price measurement. "The huge significance of the level and trend of retail prices for the national economy, for determining the purchasing power of the chervonets [ruble], for determining the real level of the workers' wages, and for determining economic relations between town and country," he wrote, "is obvious to all" (Annexe 2, section I).

This neglect of fundamentals was a source of impatience to at least one participant, Stalin: the wide-open scissors, he insisted in debate, "are opening up a rich field for private capital and are establishing favorable conditions for 
disruption of the alliance [between the peasants and workers]" (§89). He quoted lengthily from the central committee resolution of the previous April: "the success of the further progress of grain procurements - including fulfilment of the export plan and the real growth of wages, and accomplishments in the struggle with private capitalist accumulation depends completely on the continued reduction of retail prices for industrial goods and agricultural products. The attention of the trade unions, state industry, state agencies, and especially cooperatives, should be focused on this struggle in the immediate future" $(\$ 90)$.

Although the overarching aims of the policy of price cuts were not strongly articulated in the Politburo, where they did emerge there was a rough consensus. Cutting industrial prices was intended to draw both the workers and the peasants into the process of socialist industrialization and economic development. The "alliance" of the peasants and workers envisaged urbanrural trade as a cooperative, positive sum game: through trade, the peasants could obtain the industrial commodities that they needed, and supplying the state in return with food and raw materials for the urban workers and soldiers, industrial production, and exports. Cutting retail prices of industrial commodities could raise real wages, reduce worker discontent, and offer the peasants more advantageous terms on which to engage in trade.

Or could they? Outside the Politburo, this policy was criticized from the left and from the right. Expert advice from the finance ministry (cited by Carr and Davies 1974, pp. 716) was to allow prices to find their equilibrium level. Some basic economic reasoning (set out in more detail in the appendix to this chapter) suggests why. If the price of a good falls, demand will increase. The market will remain in balance only if there is a matching increase in supply. In 1923 the Bolsheviks had forced down the prices of industrial goods against the resistance of the newly formed syndicates, or wholesale supply monopolies, in state industry. The price cuts had promoted the recovery of industry because its spare capacity could support a large increase in supply.

But the same did not happen a second time. What the Bolsheviks had not fully realized was that in 1923 they had managed to cut prices and preserve equilibrium because the price cuts were accompanied by a rise in industrial production that was immediate, not planned hopefully for the distant future. By 1927, the progress of the industrialization programme was already imposing strains on industrial capacity. State industry generally had much less spare capacity than four years before. The rapid growth of capital goods production to meet the needs of the investment programme left little capacity to meet the needs of the retail market. As a result, the output of consumer goods and farm implements was restrained.

What was to be expected in 1927 if the policy succeeded and prices were cut, but the supply of manufactures did not respond? Growing shortages were inevitable; indeed, by 1926/27 there were already widespread shortages of manufactures, known at the time as the "goods famine" - a famine of industrial goods as opposed to a conventional food famine. Particular shortages could be met to a limited extent by forced substitution: Liubimov, for example, told the Politburo how industrial suppliers were compelling retail networks to substitute unwanted fish products, soap, and glassware for those 
ordered $(\S 180) .{ }^{8}$ But the fact is that the policy of price cuts was deliberately focused on those mass consumption goods that were already least available. The previous decisions of STO, Mikoian reported, had singled out for 10percent price reductions "the following deficit commodities: fabrics, leather, nails, iron, and so forth," which he also described as "the most widely sold" (§7, emphasis added). They were selected for price cuts, apparently, on the grounds that trade markups were already higher for deficit goods and gave the most scope for reduction. This ignored the probability that higher markups reflected greater scarcity; price cuts for deficit commodities also offered the greatest scope for further unbalancing the market.

Given the goods famine, there was more than one possible outcome. One alternative was simply to accept a policy defeat, abandon the price cuts, and allow the market to return to equilibrium. There would have been a political cost, however: the Bolsheviks would be seen to have broken a promise.

Alternative outcomes were arguably as bad or worse. One claimed purpose of the policy of price cuts was to create advantageous terms for the peasants to sell food to the state. But there was no advantage to the peasant if, beyond a point, they could not buy manufactures at any price. Beyond that point, the only effect of industrial price cuts would be to reduce the sums the farmers would need to raise to buy the manufactures actually available, and so cut the quantities of food that the farmers would bring to the market. In a market that was already out of equilibrium, cutting the prices of industrial goods would be actually counter-productive in terms of stimulating food supplies.

There could be further unintended consequences. The state could lose control of the market for industrial goods, and even of industrial production. The widening shortages of industrial goods would create strong incentives for private traders and private producers to enter the market. Even if supply remained unchanged, it would be advantageous for traders to buy up state goods at low official prices and sell them on to consumers at high equilibrium prices. Consumers would end up paying the same prices as before. The private traders would collect some or all of the profits that could have been made by the state. The Politburo debaters called this "speculation": thus, Mikoian declared, "I am not against accumulation [i.e. profit seeking], I am for accumulation." Voice: "Obviously." Mikoian: "If it's on the basis of properly organized work, not through price inflation and speculation" ( $\$ 39-41)$.

The gap between low official prices and high market prices could also motivate private producers to enter the market and supply the missing manufactures, aided by the fact that "the peasant sells his wares at half the factory price at most" (Rykov, §217). Private industry supplying the retail market would grow while the socialist sector would remain static. This shift in relative proportions is what Stalin feared when he mentioned the "struggle with private capitalist accumulation" and the threat to the "alliance" between the peasants and workers" $(\S \S 89,90)$ : when the peasants were selling to private traders and artisans, not to the state, they were at risk of becoming detached from the alliance.

${ }^{8}$ I.E. Liubimov (1882-1937), in January 1927, member of the party central committee; also chairman of the board of Tsentrosoiuz, the central union of consumer cooperatives. 
It is generally understood that prices play a number of roles in a market economy: ideally they signal scarcities; attract resources to high-profit uses; balance supply and demand so that markets are cleared without undesired excess capacity or frustrated consumers; and they distribute income between wages, profits, and rents. The Politburo discussion was almost exclusively focused on the distributive aspect of prices; participants saw high industrial commodity prices primarily as redistributing income away from urban and rural households to profits, and they were not thinking at all about the need to balance supply and demand. Although nobody in the Politburo quoted Marx, this emphasis was, perhaps, characteristically Marxian.

The other voice excluded from the Politburo was the Left opposition's. In earlier years both Piatakov and Preobrazhenskii had urged that industrial prices should be maintained or increased. ${ }^{9}$ This was because they favored the redistribution of income towards industrial profits in order to finance industrialization; they were not concerned about market equilibrium. Trotskii's own attitude was equivocal: he was against an increase in industrial retail prices on tactical political grounds, but he did favor an increase in wholesale industrial prices so as to channel profits out of trade into industry. During 1926 Piatakov also advocated this intermediate position. One result of the hedging and fudging was that the opposition came to appear divided and without a clear alternative to that of the leadership (Carr and Davies 1974, pp. $717-723) .^{10}$

In terms of market equilibrium, however, the policy of actually reducing retail prices made sense only if the state sector could respond by rapidly increasing the supply of products to the market. This was expected to be the result of the industrialization programme - eventually. In fact, however, the discussion reflects profound disappointment with the immediate results. Rykov complained: "Does industrialization offer anything for price cuts this year? It doesn't. Not even in the branches of industry, such as glass, that we have mechanized more than others. STO was told recently that mechanization has been carried out in such a way that glass prices will rise this year." Voice: "Why?" Rykov: I asked the same question myself, but I got no clear answer. Sergo [Ordzhonikidze] is currently in correspondence with the glass factories on this issue. We've built factories that are better than 'in Europe' but glass prices have become even more expensive." (§§192-194). Kosior reported that "the workers asked me: 'Why are prices for baked bread not coming down, when we can buy grain more cheaply?' I myself don't know why bread prices are unchanged." Rykov: "It's the 'mechanization' of baking." Kosior: "We see this sort of thing everywhere" ( $\S 321-323)$.

Stalin was the only one to suggest an explanation: mechanization of industry, coupled with outdated work norms and piece rates, often "progressive," was driving wage earnings upward faster than worker

\footnotetext{
${ }^{9}$ Iu.L. Piatakov (Georgii) (1890-1937): in 1927, deputy chairman of VSNKh, the ministry of state industry and member of the chief committee for foreign concessions. E.A. Preobrazhenskii (1886-1937): in 1927, member of the chief committee for foreign concessions.

${ }^{10}$ L.D. Trotskii (1879-1940): in 1927, chairman of the chief committee for foreign concessions.
} 
productivity. In other words, the workers were capturing the gains from industrialization at the expense of the state. ${ }^{11}$

To summarize, the Bolsheviks had adopted a policy of industrial price cuts in the belief that it would reconcile the competing interests of workers, peasants, and the state. This belief was ill-founded. It rested, however, on recent experience: in 1923 the Soviet leaders had implemented a similar policy with apparent success. In 1927, the same leaders felt they now understood the market economy and had proved their ability to manipulate it. They did not see that circumstances had changed: their previous success had depended on expanding industrial production of consumer goods to keep pace with the market expansion that price cuts enabled. In 1927 a significant range of consumer goods was already in short supply and these shortages would soon worsen.

If, in 1927, Mikoian, Rykov, and Stalin had listened more carefully to those with a better understanding of market economics, would they have chosen differently? We cannot know for sure.

Possibly, they did not yet have the full courage of their convictions. In April 1928, for example, Bolshevik policy wavered briefly away from confrontation with the market and back to accommodation (Carr and Davies 1974, pp. 65-6; for a fuller account of this episode based on the archives see Manning 2001). "It would be premature," Carr and Davies concluded, "to assume that at this time a majority of the leaders, or Stalin in particular, was committed to coercion, or had decided to abandon the methods of the market for a policy of direct action."

But we do know this. By 1929 they could see the consequences of their actions in full measure, and they did not draw back. This is because they attached no importance to market equilibrium. They were looking not for equilibrium, but for direct control over prices and allocations. In early 1927 it frustrated them that they were nowhere near achieving this, and in early 1928 they vacillated. In 1929, faced with a naked choice between market equilibrium and going over to a command system ruled by force, they chose command.

The fact that this crisis was not precipitated even more rapidly can be ascribed to a simple fact that occupied much time in the Politburo: in January 1927 the policy of industrial retail price cuts was proving extremely difficult to implement, and was encountering resistance from many sources. Whether or not price cuts were desirable, it was not clear that they were feasible. The difficulties evoked two lines of discussion: what were the main obstacles to implementation of the policy? And by what means should it be enforced?

\section{Feasibility}

If retail prices were so stubbornly high, what was the reason? Simplifying a little, Figure 3 shows how the retail prices of state manufactured goods were formed in the 1920s. There are four preliminaries to note.

${ }^{11}$ Work norm revision would remain a critical issue for Soviet industrial policy and labor relations through the following decades (e.g. Arnot 1988, pp. 84-87; Davies and Khlevnyuk 2002) 
First, the government directly determined some costs, for example freight charges and sales taxes; the government could cut prices by reducing its levies, but then it lost budgetary revenue as a result. Second, profits were accounted for, properly, within the markups that producers and sellers claimed at each stage. The Bolsheviks were not against profits as such, but they generally wanted profits to be made out of trading at approved prices using approved markups. Third, the producers and sellers themselves reported production and distribution costs, so there was scope for inflating costs at each stage. The inflation of costs could be real, in the sense that resources were used up inefficiently, the gain to the producer being a quiet life; equally it might take the form of concealed profit-taking, so that costs were exaggerated and cash flows diverted into unauthorized institutional accounts or private pockets.

Fourth, it is clear that most participants had little or no confidence in the quality of the price data they were discussing. They wanted to make a policy instrument out of a variable that most believed they could observe only poorly, with a wide error margin. Mikoian discussed measurement explicitly and came armed with tables of trends in factory, wholesale, and retail prices (Annexe 2), the accuracy of which Liubimov defended $(\S 143)$ - but no one else did, and even Mikoian conceded: "I don't know how reliable these figures are but their sources are all documented and more precise data are not to be found anywhere" $(\S 31)$. There was also understandable concern that the averages neglected significant variation between town and country and among regions. Whether or not Mikoian's figures were accurate, they were not politically credible. The discussion was relatively uninformed about trends in productivity, costs, or other relevant price-forming variables. In addition the concept of markups on costs proved intractable for non-specialist discussion; some participants struggled to understand what was included in this markup or that, while others lacked any clear way of expressing a change over time in a share of a variable that was itself changing.

Starting from the top, we have already mentioned one factor in the retail price level: the persistently high production costs of industry. Eismont, for example, pointed out that existing retail margins were simply not large enough to explain more than a small part of the widening of the scissors compared with the prewar period $(\$ 226) .{ }^{12}$ Industrial production costs were the elephant in the room. They were not completely ignored; as we have seen, both Rykov and Stalin made the point that industrialization was not cutting production costs as fast as expected. Other speakers focused on lesser issues, perhaps because they were looking for quicker results. More common was the standpoint of Mantsev, who asserted plainly that "if industry wholesale prices went up over this period, then they went up by 1 to 2 percent overall." (Mikoian's reply inaudible.) "... What influence could this have on the retail price level? Absolutely none. The increase in retail prices has not been caused by the ill will of industry. We have made some mistakes, of course, but in this respect it is not our fault" $(\S 85){ }^{13}$

\footnotetext{
${ }^{12}$ Eismont: details to be added.

${ }^{13}$ V. Mantsev: in 1927, chairman of the council of the industrial syndicates responsible for wholesale marketing of industrial goods, and member of the
} 
Much discussion was devoted to the size of wholesale and retail trade costs and markups, the "wholesale-retail" scissors, and the scope for pressing them shut. On this, Mikoian's written report is uninteresting; it deals only with technicalities such as credit costs and freight charges. His speech set a sharper tone, and his first significant point was that trade markups were higher than they should be, especially for deficit commodities:

Just in relation to manufactures, especially in retail trade, we have extremely high markups compared with both prewar and normal contemporary ones. Private traders in particular have big markups, but that's fully understandable. It's extremely expensive for the private trader to acquire goods, he has no direct channel for getting goods. If you look in any large private store you won't find goods in big batches, just remnants that the unemployed, janitors, and other s have bought up on commission for the private trader. In cooperation there are also big markups and in state trade too, but nonetheless all the evidence I have shows that these are not bad compared with the prewar years for commodities not in short supply. On the other hand, in so far as our trade system is structured more rationally than the private trader's, and we have centralized trade, largescale associations, and so on (the socialist system ought to be rational, and we ought to be establishing a transitional distribution apparatus), we can’t define prewar markups as our ideal; we ought to squeeze them (§31).

Mikoian went on to suggest that profit seeking in trade organizations was the main obstacle to price cuts: "our [ministry of] internal trade," he complained, "isn't able to make people cut prices because they often think price cutting is good, but accumulation is better (laughter)" (\$35). Stalin labored the same point:

Among cooperative workers and our trade workers has recently formed a dangerous psychology and a dangerous aspiration toward achieving 'glittering' bottom lines (balansy) with 'glittering' profits. The cooperative workers are more and more aiming not to strengthen the alliance of worker and peasant consumers, but to accumulate more profit and then glitter with the bottom line. This, comrades, is a dangerous psychology and a dangerous aspiration that can lead to no good. We need neither glittering bottom lines nor high profits. This is not our policy. We need an alliance of the broad mass of consumers of the towns and countryside. Let there be less profits and let there be no glittering bottom lines, but let us strengthen the alliance of our industry, through the trading agencies, with the mass consumer. This is our policy. Unfortunately, our cooperatives do not understand or do not want to understand this. And this is now the main danger $(\S 119)$.

Others also singled out profit seeking for criticism. The outstanding contribution on this score was Bukharin's. "Industry is developing more rapidly than agriculture," he began, "but the state of affairs ... in the field of relations between the working class and the peasantry is standing still. Explain what's the matter? I know of no other explanation [but that] we have hidden

board of VSNKh, the ministry for state industry (Carr and Davies 1974, p. 403). 
accumulation that is not being passed on to us." Voice: "True." Bukharin: "There is accumulation in the field of industry, and in the field of trade, and cooperation, and they are hiding this accumulation from us. The business stinks not of tens but of hundreds of millions" ( $\S 329-331)$. By "hidden accumulation," Bukharin evidently meant profits that were not being reported to the government but held in secret. Then, a comic kind of auction took place over the estimated profits of Tsentrosoiuz, the central cooperative trading agency, that Stalin eventually won:

Bukharin: "In my view it must be generally acknowledged that there is hidden accumulation, but it's not being reported to us."

Stalin: "There is, without doubt, there is."

Bukharin: "It's a question of profits."

Stalin: "120 million."

Mikoian: "175."

Bukharin: “About 200” (§§338-343).

But Stalin placed the winning bid a few minutes later:

I think if you count the hidden profit too, the profit can go to 250, maybe to 300 million. Who needs this deception and what are these super-profits for? Who can be unaware that these super-profits can lead only to the decay of our commodity supply network and the detachment of the part and state from the mass of consumers numbered in millions? (\$412).

Not all of those present were opposed to profit seeking. Kuibyshev, for example, first complemented Mikoian's argument by suggesting that deficit commodities typically commanded huge markups, especially in the free market ( $\$ 125)$; he went on to point out that cooperatives could then profit by slightly undercutting free market prices. ${ }^{14}$ When challenged, however, Kuibyshev would not speak out against profit as such. He argued that trade profits were a problem because they were lost to industry; industrial profits were needed to finance industrialization $(\S \S 131,133)$. This argument came close to that of Piatakov and the Left opposition at the time, but the closeness arose partly because the Left had deliberately blurred its own line. Ordzhonikidze also spoke up for industrial profits: "About hidden accumulation ... Certainly they hide it. Of course not for themselves, but in order to expand local industry. You can cut wholesale prices but I believe that if our goods distribution network will absorb the same amount as now, no matter how much you cut, nothing will come out. I worry that we will tell Kuibyshev to cut [prices] but the reduction will not reach the consumer" $(\S 396) .{ }^{15}$ Going further, Liubimov was willing to stand up for trade profits too:

${ }^{14}$ V.V. Kuibyshev (1888-1935): in 1927, member of the party central committee; also minister for state industry as chairman of VSNKh, the allunion council of the national economy.

${ }^{15}$ G.K. (Sergo) Ordzhonikidze (1886-1937): in 1927, chairman of the party central control commission; also minister for Rabkrin, the workers' and 
"If you make us sell 10 or 50 commodities at a loss, and forbid us to make a profit on the other 10, it's obvious that our organization will fly away, carrying a loss overall” (§146).

Other participants were concerned not about high profits in trade but about high costs. Andreev noted a rapid growth of total employment in cooperative trade in 1925 and 1926, despite frequent complaints that the shortage of commodities left the cooperatives underemployed $(\$ 264) .{ }^{16}$ Ordzhonikidze gave anecdotal support to this. He described a typical rural cooperative store staffed by four workers, in place of one before the war; when asked the reason, he was told that "one can steal, whereas these will watch each other." But "if all three conspire to steal," he retorted, "there'll be nothing left in the shop ... let comrade Liubimov or someone prove to me that this is not the case." Liubimov. "I haven't proved it" ( $§ 389-390)$. But Liubimov had argued that commodity shortages themselves were raising the search costs that trading agencies had to bear, since their procurement agents now had to travel far and wide to locate supplies $(\S 179){ }^{17}$

Towards the end, Stalin weighed in decisively. It did not really matter whether the problem was high profits or high costs in the retail sector. "At the expense of what must the policy of retail price cuts be implemented? At the expense of the apparatus of the trading agencies, at the expense of cutting their staff, at the expense of cutting their overhead costs, at the expense of cutting their profits. There are no other sources. This we must understand and from this we must proceed. This is why cutting markups is the immediate task" (§406). Stalin concluded with a brutality of expression that was already his characteristic: "We must, before anything else, implement a serious reduction of retail prices for industrial commodities of a mass character both in the countryside and in the towns, beating down the markup, reducing the markup, breaking the resistance of the cooperatives and other trading agencies at all costs" (\$418, emphasis added).

If Stalin felt that he had closed the debate, Kalinin, the last speaker, did not seem to notice. He was clearly sceptical of the Politburo policy; "A while ago," he confessed, "we thought that retail price cuts were literally the panacea that would save us, but now we see that this is not so" $(\S 420)$. He was for cooperatives' profit seeking: "profit is not a dangerous thing in cooperation," he argued on the grounds that cooperatives pay a dividend to their members, returning the profit to the consumers $(\S 422)$. As for high trade costs, Kalinin talked about how the revolution had improved the position of service sector workers, disproportionately raising trade costs; "Why do we pay 5 kopecks for bread? Because that's what it costs ..." (§425). This dissent did not meet with any rejoinder or rebuke, although it is reported at one point that Kosior interrupted by coughing "ironically" $(\S 429)$.

peasants' inspection; deputy chairman of STO, the council of labor and defense; and deputy prime minister.

${ }^{16}$ A.A. Andreev (1895-1971): in 1927, candidate Politburo member; also chairman of the central committee of the union of railroad workers.

${ }^{17}$ This appears to be an early reference to the role of the tolkach in the Soviet economy later described by Joseph Berliner (1957) and others. 


\section{Enforcement}

Mikoian appears to believe that the policy adopted the previous spring of cutting key commodity prices by 10 percent could not be driven further. He put this down to the fact that the Bolsheviks were not yet really in control of the market for manufactures. He suggested this by contrasting the bad state of the market for manufactures with the good state of the grain market; this also usefully illustrates what kind of control the Bolsheviks aspired to:

... we have reached a point such that peasant muddle and the peasant grain market are wholly and completely in our hands, we can raise or lower grain prices at any time, and we have all the levers of influence in our hands. But in relation to state trade and the cooperatives, we don't have these levers for industrial commodities, or, more accurately, we utilize them badly. At present it is easier to raise or lower grain prices in a short period of time across the entire union territory, and more difficult, and it demands unbelievably more effort, to cut prices for industrial commodities in the state-trading or cooperative sphere, because no one stands up for the peasant (muzhik) and gets in our way, whereas various organizations stand up for cooperation and state trade and defend them. There turns up some comrade or other from cooperation and state trade and he says we can't cut prices just like that, there has to be a profit, they're all good lads - and the result is none of the necessary pressure and none of the necessary results.

Here we have the situation that state and cooperative organizations, that are socialist-type organizations, are less subject to the influence of the state and its leadership than the private market for grain.

... it may be that the upper layer of the cooperatives has recently been supporting us and wants a reduction, but this is not true of the whole cooperative system and all local agencies $(\S \S 8,9,11)$.

Mikoian had reached a surprising conclusion: it was easier for the state to control millions of farmers through the market than to exercise effective authority over a dozen or so ministries and a few hundred industrial trusts. His words have the sound of reality knocking at the Bolsheviks' door. They wanted to socialize the market economy. Now they had a new problem: who controls the agencies of socialization?

Given his sense of the limits of state power, Mikoian was apparently opposed to calls for radical price cuts and wanted to pursue a realistic target of a 2 to 3 percent overall reduction. His interventions are pervaded by a sense of bureaucratic impotence; even if "state and cooperative organizations ... are less subject to the influence of the state and its leadership than the private market for grain," he lamented, it was also true that "we have few means of influence over private capital" (§7). He described his own trade ministry as not only "weak in the centre" but also understaffed locally; each provincial office employed no more than " 15 to 20 persons including messengers, cleaners, and others" (§13). He believed little could be achieved without the involvement of local party organizations and the mobilization of mass pressure on trade costs and prices $(\S \S 33,44)$. Later in discussion Liubimov pointedly criticized party and trade union organizations for "frosty" (prokhladnoe) neglect of the policy of price reductions $(\S 184)$. 
They could only get so far with what one speaker, Mantsev, ridiculed as an "evangelical" style of work: "we recommend, we request, we suggest" (§62). Stalin suggested adding public pressure through use of the press to expose pricing abuses (\$118). But in closing the debate, Mikoian made a striking admission of weakness that Kosior immediately rejected:

"I want to say one thing -- whatever measures we adopt, whatever proposals all the Politburo members agree on for cutting prices by squeezing trade costs, we cannot achieve the kind of retail price reductions now, or within two or three months, that can pacify the workers and peasants in the smallest degree"

Kosior: "That's not proven" (§§454-455).

But, if not party mobilization and public pressure, then what? The alternative was police measures and repression. The new RSFSR criminal code that came into effect on January 1, 1927, made the "malicious raising of prices of merchandise by way of buying up, concealing, or with holding from the market" an offence punishable by imprisonment (Carr and Davies 1974, p. 724). Several of the papers received by the Politburo dealt with local party organizations' involvement in discussion and implementation of price cuts. The last of these is entitled "Holding to Account of Organizations and Persons Not Implementing the Directives of Party Agencies on the Reduction of Retail Prices" (Annexe 11). It lists a dozen regional committees that had issued resolutions calling for reprimands, dismissals, and prosecutions for lack of whole-hearted compliance with the policy.

While it is not clear that these threats specifically had been carried out, something was going on. Early in the discussion, Mikoian noted that, while some were "complaining that repressive measures have not been applied ... there are already 600 cases of repressive measures against trading agencies in the [Russian republic]. There is no solution," he warned, "in repressions alone, since repression is an auxiliary weapon that cannot replace all the forms of economic positions in the market" $(\S 45)$. Eismont confirmed subsequently that the 600 cases of "repression" were indeed prosecutions (§259).

Stalin's various contributions show three recurrent themes. First, he resolutely defended the role of the party, rejecting all criticisms ( $\S 88-106)$. Second, it was not enough for state or party to make decisions; they must also monitor progress towards implementation. Stalin saw a pattern, wider than the narrow issue of retail prices, in decisions that disappeared into an administrative vacuum. STO had adopted a resolution calling for shorter retail supply chains. "Is this decree of STO being implemented?" he asked, giving the answer: "No, it is not being implemented"; and another question: "Why?" (§409). Again, STO had adopted a resolution to close state trading outlets where they duplicated cooperative networks. "Is this decree of STO being implemented? No, it is not being implemented. Why?" (§410). He criticized Mikoian for not providing evidence of whether a decision of STO to reconstitute trading agencies that resisted the price cuts had been carried through $(\S 106)$.

Stalin's third preoccupation was with the power of state to force radical change. This is where his dispute with Mikoian emerged most clearly. Mikoian wanted to set a realistic target of a 2 to 3 percent overall reduction. 
Stalin, wanted more and did not see why it should not be imposed by force, by an act of political will. This led to a satirical exchange:

Mikoian: “... generally, on average, prices can be cut by 2 to 3 percent.”

Stalin: "By two kopecks off the ruble?"

Mikoian: "Roughly. That's in the immediate future."

Stalin: "It's not enough."

Mikoian: "I would like it to be more, but I can't issue instructions that no one can fulfil. I am a supporter of those instructions for our administration that have 80 to 90 percent feasibility. If you issue an instruction in which 60 percent is feasible and 40 percent is infeasible, then this will disorganize the administration. We are currently shouting that they are not implementing the directive, but they are not arresting us and jailing us for it; comrade Liubimov is not in prison and I haven't been arrested. They aren't carrying out all instructions, but no one has been handed over to the courts to answer for it. But when it comes to grain, and Lobachev doesn't comply with an order, they dismiss him and jail him."

Voice: "What do you want, for them to jail you, and then everything will be all right?"

Mikoian: "Arrest me, I'll happily go to prison so as to sleep well."

Voice: "How long do you want to go to prison for?"

Mikoian: “About six months" (§§458-466).

Finally, how did the Bolshevik leaders see the expected consequences of failure? The Bolshevik leaders clearly expected to pay a political price if they did not press on with the policy they had previously announced. They also no doubt feared what the opposition would say if the policy failed. Mikoian worried that, with no results in six months, "the masses will say that we deceived them and that prices haven't been cut enough" (\$51). Kosior warned explicitly of the likely damage to the party's credibility: "Our discussions today remind me of what's happening at meetings where we talk about our achievements and about how prices have come down and so on, and the workers grumble: 'The devil take you, you have all those achievements and we don't feel a thing." A few days ago in Kazan' I was demonstrating that we have cut prices but the workers don’t believe it” (§308).

Implicitly, Kosior sided with Stalin against Mikoian on the size of cuts that were required; the public would simply not notice a deflation of the order of 2 or 3 percent. "In the trade ministry," he mocked, "you weigh price cuts on a pharmacist's scales, and you calibrate them in units of the order of 0.05 , but in life it looks otherwise" (\$309). He concluded: "We have talked about price cuts for a whole year. They are looking to us now for actions, not resolutions" (§311).

The Politburo meeting was indeed followed by action. Between January and October 1927 there was a concerted campaign of decrees, propaganda, and mobilizations in which Mikoian and his ministry of trade played a leading

\footnotetext{
${ }^{18}$ Lobachev: details to be added.
} 
role. It had the effect of lowering official retail prices of industrial goods by more than 7 percent - much more than the " 2 to 3 percent" that Mikoian had modestly urged in January. As a result, shortages multiplied; the peasants became increasingly unable to buy from the state and increasingly reluctant to sell to it (Carr and Davies 1974, pp. 724-30). Mass operations of the OGPU security police and mass arrests in the countryside formed the core of the "extraordinary measures" adopted at the end of 1927 to bring in the grain from that year's harvest (Manning 2001).

\section{Conclusions}

In 1926/27 the Bolsheviks were pursuing a policy of downward pressure on retail prices of industrial commodities. In the Politburo there was broad agreement in support of this policy in principle, but clear differences over how far it should be pursued and where to accommodate to economic and social resistance. Some special interests were voiced; there was a clear tendency for those with an interest in industry, such as Ordzhonikidze and Kuibyshev, to seek to push the burden of adjustment onto trade, and for those with interests in trade or cooperatives, such as Liubimov and Kalinin, to defend them. A significant middle ground wished to pursue price cuts only in moderation and within limits. To one side, Stalin rejected all compromise; on the other side, only Kalinin expressed reservations that could be construed as principled objections.

The party's policy of industrial retail price cuts was a significant factor undermining the market economy and contributing to its eventual replacement by a command system in which resources were allocated by force. It worked at four different levels. Each can be seen clearly in the minutes of the Politburo.

First, the policy promoted market disequilibrium. This in itself was not of concern to the leadership core, which did not set any special value on a balanced economy. However, the particular form of disequilibrium that the policy promoted was that state-supplied manufactures became increasingly unavailable at the low prices resulting from downward pressure. Shortages spread, with predictably adverse effects on the peasants' willingness to bring their food to the market. Eventually, the threat to agricultural supplies for urban households, state industry, the Red Army, and exports led the Bolshevik regime into a direct confrontation with the peasantry that ended in collectivization and famine.

Second, the policy was a step in the process that made price setting a political, not economic decision. Once the state took responsibility for setting prices, it had to accept that industrial managers could no longer be held accountable for profits or losses, and would become indifferent to costs. Thus the government's price controls promoted the softening of budget constraints faced by state-owned enterprises and encouraged them to use up resources in production and distribution that might otherwise have been available for raising living standards and developing the economy. It led directly, therefore, to the inefficiencies of the command system.

Third, the party's policy evoked resistance; the resistance evoked a search for the people impeding the policy in the private market, in the cooperative trading agencies, and in the state retail sector. This search was accompanied by calls not only for mass pressure to counteract the resistance, but also for 
direct repression of the resisters. The politicization of price setting in general led, by this direct route, to the criminalization of the specific pricing decisions that the party perceived as undermining its policies.

Fourth and finally, Stalin was able to exploit the issue to promote his claim to personal leadership. As we watch the Politburo members debate the issues, Stalin emerges as the chief defender of the party, its policies, and its organizations. We see Stalin's rhetoric at work in this role. It is like a bulldozer. Link by link, its metal tracks crush all obstacles. The party must hold its line at all costs. The resisters are a source of danger; those who cover for them have misplaced their loyalties and priorities. The resistance must be broken, by persuasion if possible, by force if necessary. That is all. 


\section{Appendix: Price Cuts and Market Equilibrium}

This appendix sets out explicitly the reasoning used in section 1 of the text to explain the effects of industrial price cuts in the Soviet retail market. In Figure 4 peasant farmers supply food which, measured vertically, is traded against state-manufactured goods, measured horizontally. The equilibrium is found where two lines or "offer curves" intersect at point A, and the state exchanges $M_{0}$ manufactured goods for $F_{0}$ food. The slope of the line from the origin to A, measured by the angle $\sigma$, measures the real price of industrial goods: when the scissors open, $\sigma$ increases and the line becomes steeper, and conversely when the scissors close.

The analysis takes the nominal price of food as given, as the Politburo had to, since grain prices were to be considered in a separate report (Mikoian, $\S 451)$. They assumed that a cut in the nominal price of a manufactured item measured in rubles and kopecks is also a cut in its relative price measured in food units; and in our model $\sigma$ is therefore the relative price.

The convex OF curve shows the peasants' offer of food in return for manufactured goods; it is convex because of diminishing marginal utility, which made the peasants increasingly reluctant to give up food in return for manufactured goods as their consumption basket shifted away from food to manufactures. An increase in agricultural productivity would shift the OF curve upwards, since cheaper food would make farmers willing to give up more food for an item of manufactured goods. In equilibrium, the size of the urban-rural market would grow.

The straight, upward sloping OM line shows the manufactured goods that state industry was willing to offer the countryside in return for food. Its slope measures the price at which manufactures were offered. It is straight because the price was fixed independently of quantities: state industry had market power and used this power to pre-set the price of manufactures before going to the market. The basis of price-setting was a markup on costs. Real costs were determined by industrial productivity. The size of the markup on costs then depended on the state's use of its market power. A reduction in the markup and a reduction in industrial costs would each close the scissors and swing the urban offer curve to the right; either of these would expand the urban-rural market. This theoretical proposition, once much debated, has been verified empirically for the Soviet economy in the 1920s by Gregory and Mokhtari (1993.)

The background to policy discussion in January 1927 is illustrated in Figure 5. Starting from point A, the leadership had decided to expand the market by cutting the price of industrial goods, reducing the slope of the OM curve to $\sigma^{\prime}$ and shifting the curve to $\mathrm{OM}^{\prime}$. At the new price $\sigma^{\prime}$ the peasants would offer $F_{1}$ in exchange for $M_{1}$ manufactures. Provided the state could increase the supply of manufactures to match, the market equilibrium would shift from A to point B. With more food available, real wages could rise and industrial employment could grow. This is what had happened in 1923, but the same did not happen a second time. What the Bolsheviks had not fully realized was that in 1923 they had managed to cut prices and preserve equilibrium because the price cuts were accompanied by a rise in industrial production that was immediate and simultaneous, not awaited hopefully in the distant future. 
What happens when prices are cut but the supply of manufactures by the state is fixed at $M_{0}$ ? In Figure 4 the $\mathrm{OM}^{\prime}$ curve is only the state's notional offer. Its slope is the price at which industry offers manufactures to the countryside, but beyond the quantity $M_{0}$ the state offers no goods at any price. There is a shortage of manufactures: the "goods famine." In this context there are four possible outcomes:

1. Abandon the policy of price cuts and accept the political damage of a policy defeat. The market returns to equilibrium at A.

2. Hold the price of manufactures to $\sigma^{\prime}$. With manufactures available only up to the quantity $M_{0}$, farmers will be forced off their offer curve to point C. They will sell only the food required to purchase $M_{0}$, since $M_{0}$ is the maximum they can buy at any price. In fact, they will sell only $F_{2}$ which is not only less than $F_{1}$ but even less than $F_{0}$. The party has saved its political capital but the price cuts have been counterproductive in terms of the supply of food.

3. The gap between the state price and the equilibrium price may now encourage the reselling of manufactures, allowing private individuals to collect the gap in the form of rents or bribes. The market returns to equilibrium at $\mathrm{A}$, but the state, buying and selling at $\mathrm{C}$, has lost revenue to the private resellers, who collect part of the food that might otherwise have gone to the state.

4. The gap between the state price and the equilibrium price may also encourage private producers to enter the market and supply the unsatisfied consumers. The state is no worse off absolutely, since it continues to buy and sell at A. But the private sector will grow, so the state sector's share will shrink proportionally. 


\section{References}

Arnot, Bob. 1987. Controlling Soviet Labour: Experimental Change from Brezhnev to Gorbachev. Basingstoke: Macmillan.

Berliner, Joseph S. 1957. Factory and Manager in the USSR. Cambridge, MA: Harvard University Press.

Carr, E.H. 1969. A History of Soviet Russia. The Interregnum, 1923-1924. Harmondsworth: Pelican.

Carr, E.H., and R.W. Davies. 1974. A History of Soviet Russia. Foundations of a Planned Economy, 1926-1929, vol. 1. Harmondsworth: Pelican.

Davies, R.W., and Oleg Khlevnyuk. 2002. "Stakhanovism and the Soviet Economy." Europe-Asia Studies, 54:6, pp. 867-903.

Davies, R.W., and S.G. Wheatcroft. 1994. "Population." In The Economic Transformation of the Soviet Union, 1913-1945, pp. 57-80. Edited by R.W. Davies, Mark Harrison, and S.G. Wheatcroft. Cambridge: Cambridge University Press.

Goriachev, Iu.V. 2005. Tsentral'nyi komitet KPSS, VKP(b), RKP(b), RSDRP(b). Istoriko-biograficheskii spravochnik. Moscow: Parad.

Gregory, Paul R. 1990. "The National Income." From Tsarism to the New Economic Policy: Continuity and Change in the Economy of the USSR, pp. 237-247. Edited by R.W. Davies. Basingstoke: Macmillan.

Gregory, Paul R., and Manouchehr Mokhtari. 1993. "State Grain Purchases, Relative Prices, and the Soviet Grain Procurement Crisis." Explorations in Economic History, 30:2, pp. 182-94

Harrison, Mark. 1990. "The Peasantry and Industrialisation." In From Tsarism to the New Economic Policy: Continuity and Change in the Economy of the USSR, pp. 104-126. Edited by R.W. Davies. Basingstoke: Macmillan.

Harrison, Mark. 1994. "National Income." In The Economic Transformation of the Soviet Union, 1913-1945, pp. 38-56. Edited by R.W. Davies, Mark Harrison, and S.G. Wheatcroft. Cambridge: Cambridge University Press.

Ivkin, V.I. 1999. Gosudarstvennaia vlast' SSSR. Vysshie organy vlasti i upravleniia i ikh rukovoditeli. 1923-1991 gg. Istoriko-biograficheskii spravochnik. Moscow: ROSSPEN.

Manning, Roberta T. 2001. "The Rise and Fall of 'the Extraordinary Measures,' January-June, 1928: Towards a Reexamination of the Onset of the Stalin Revolution." The Carl Beck Papers in Russian \& East European Studies, no. 1504. Pittsburgh, PA: University of Pittsburgh, Centre for Russian \& East European Studies.

Strumilin, S.G. 1958. Na planovom fronte. 1920-1930 gg. Moscow: Gospolitizdat. 
Figure 1. The Opening “Scissors, ” 1922/23

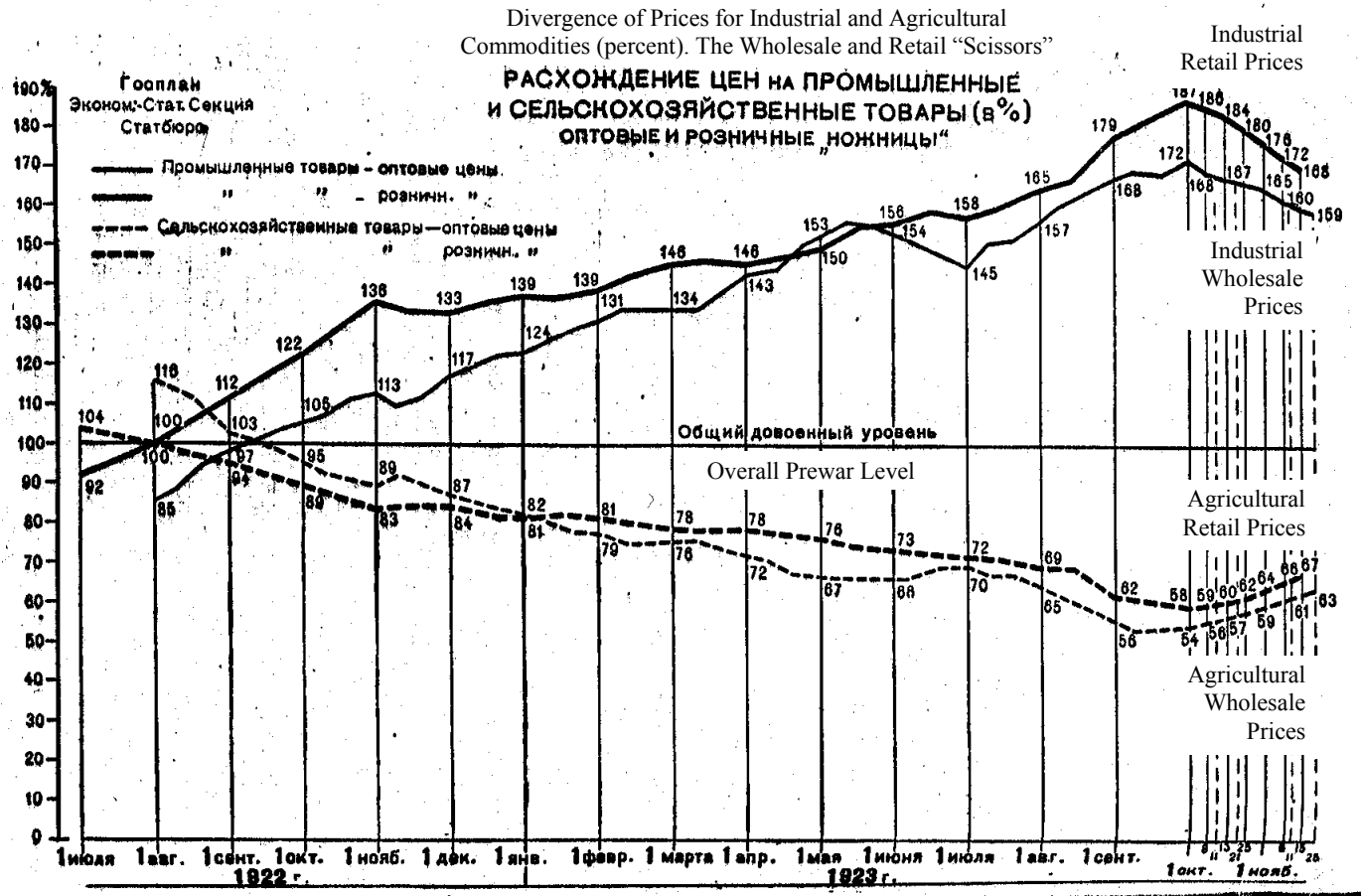

Source: Strumilin (1958, p. 64), reprinted from Biulleten' Gosplana, no. 10 (1923).

Figure 2. The Scissors Open, Close, and Reopen, 1922/23 to 1925/26

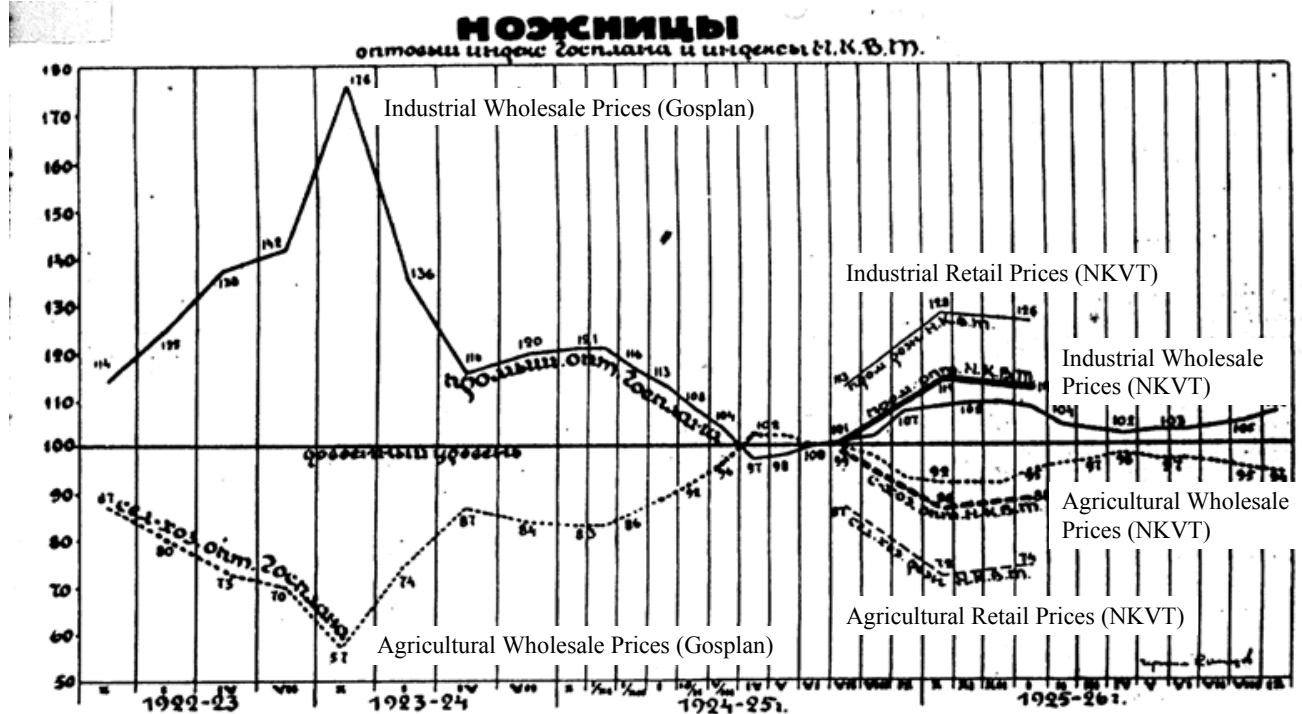

Source: RGASPI, 17/2/197, folio 66 (transcript of the Central Committee plenum, October 9, 1925). Thanks to Simon Ertz for this reference. The long series are by Gosplan; the short series, July 1925 to January 1926, are by the ministry of internal trade (NKVT). 
Figure 3. Retail Price Formation

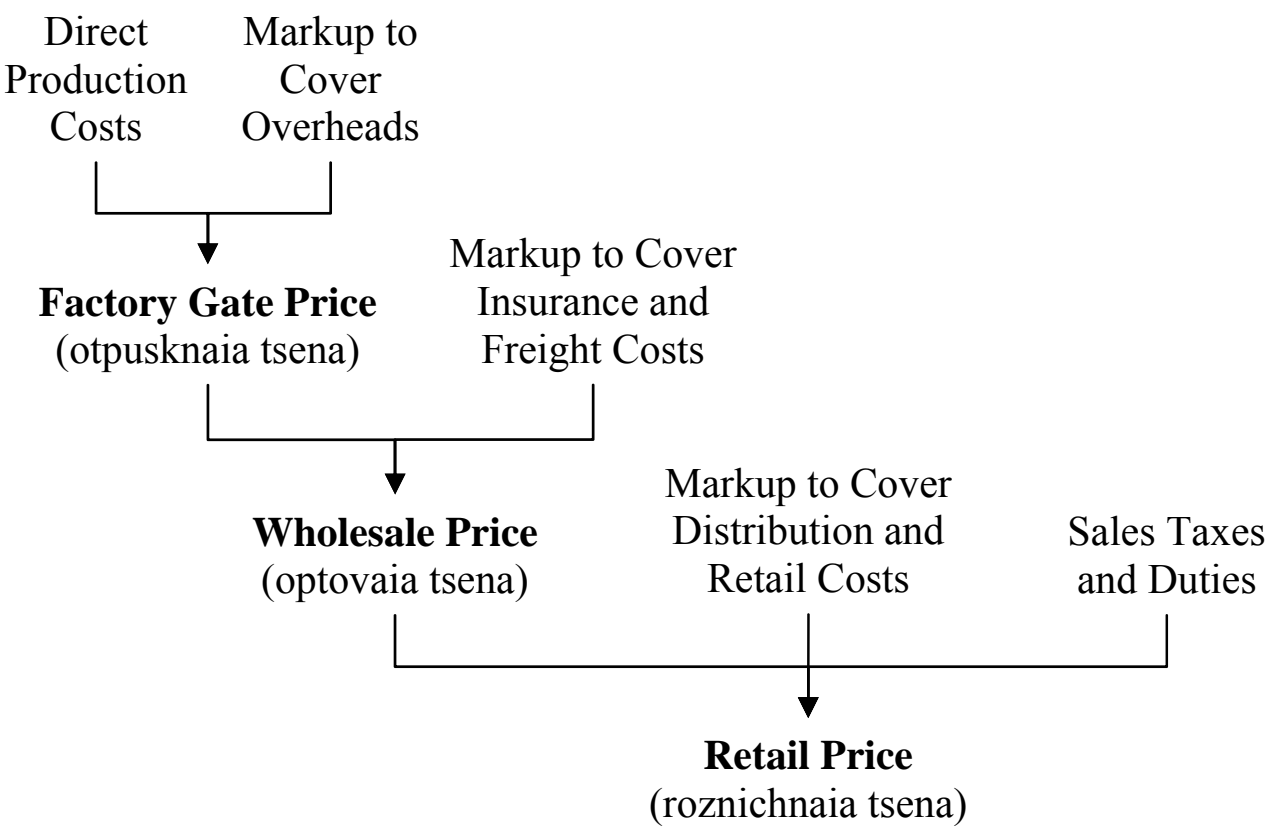


Figure 4. State Industry and Peasant Farmers in Equilibrium

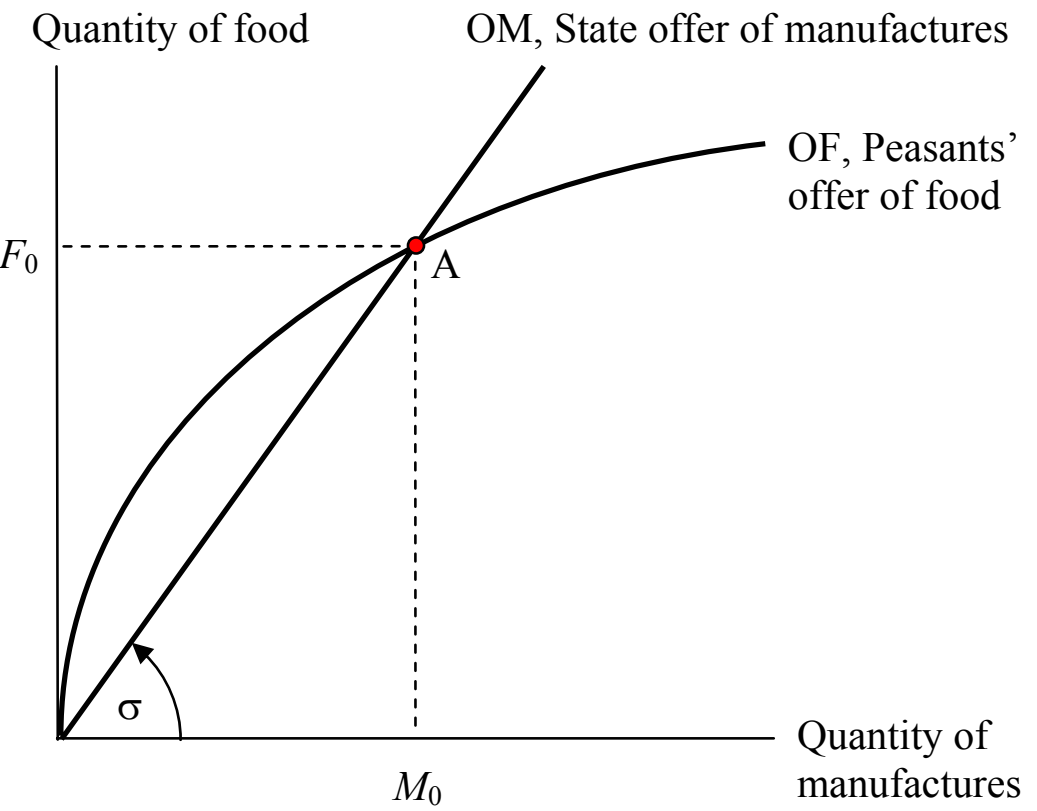

Note. The angle $\sigma$ measures the scissors, or the price of manufactures relative to food. When $\sigma$ increases, the scissors open and the real price of manufactures rises.

Figure 5. State Manufactures in Short Supply

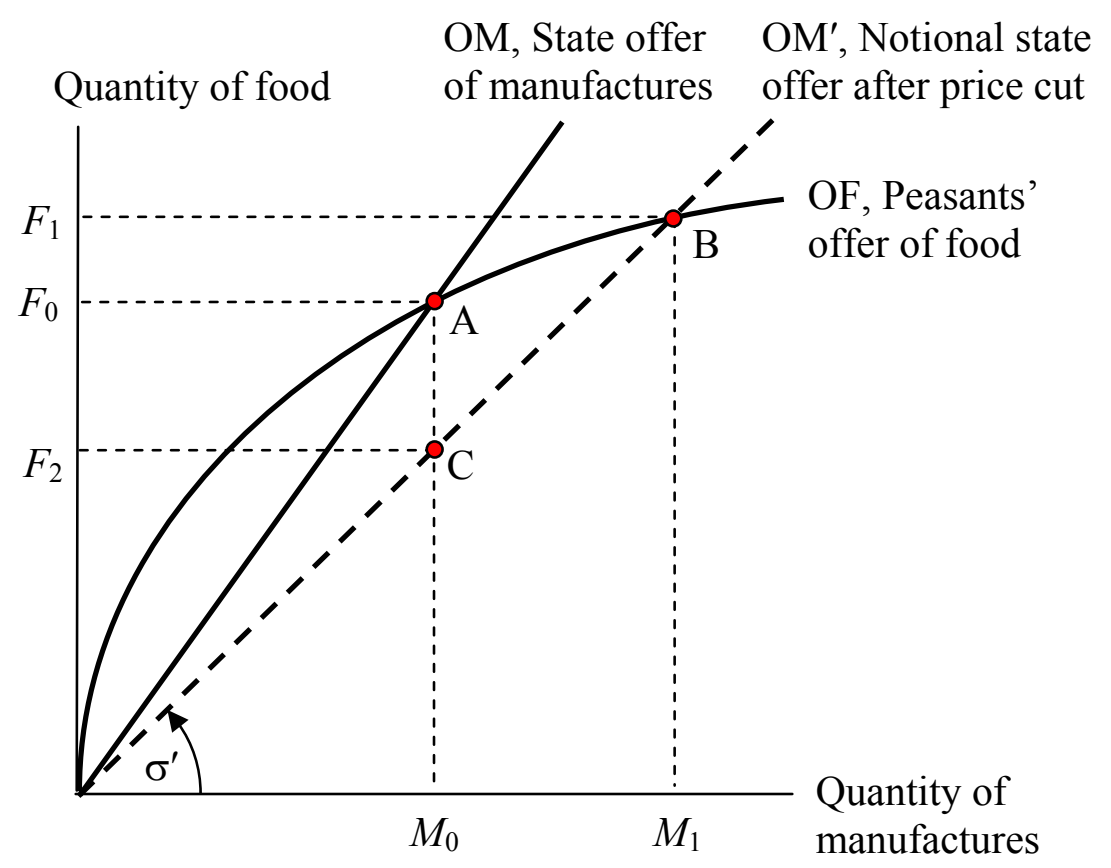

